http://dx.doi.org/10.23891/efdyyu.2017.16

ISSN:1305-020

\title{
Okul Öncesi Eğitim Kurumlarında ve İlkokul Kademesinde Görev Yapan Rehber Öğretmenlerin Mesleki Tükenmişliklerinin Karşılaştırılması
}

\section{Ramazan SAK*, İkbal Tuba ŞAHİN SAK**, Eşref NAS***}

Öz: Bu çalışmanın amacı, okul öncesi eğitim kurumlarında ve ilkokul kademesinde görev yapan rehber öğretmenlerin mesleki tükenmişliklerinin karşılaştırılmasıdır. Tarama modelinde planlanan bu çalışmanın katılımcılarını, okul öncesi eğitim kurumlarında görev yapan 72 ve ilkokul kademesinde görev yapan 143 rehber öğretmen olmak üzere toplamda 215 rehber öğretmen oluşturmaktadır. Veri toplama aracı olarak Kişisel Bilgi Formu ve Maslach Tükenmişlik Envanteri kullanılmıştır. Veriler, bağımsız örneklemler için t testi ve bağımsız gruplar için iki yönlü ANOVA kullanılarak analiz edilmiştir. Analizler sonucunda, rehber öğretmenlerin mesleki tükenmişliklerinin hizmet verdikleri eğitim kademesine (okul öncesiilkokul) göre Duygusal Tükenme alt ölçeğinde anlamlı bir farklılık gösterdiği belirlenirken, Duyarsızlaşma ve Kişisel Başarı alt ölçeklerinde anlamlı bir farklılık bulunmamıştır. Diğer bir ifadeyle, ilkokullarda görev yapan rehber öğretmenlerin mesleki tükenmişlikleri Duygusal Tükenme alt ölçeğinde okul öncesi eğitim kurumlarında görev yapan rehber öğretmenlerin mesleki tükenmişliklerinden daha yüksektir. Bununla birlikte, cinsiyet, yaş ve medeni durum değişkenlerinin rehber öğretmenlerin Duygusal Tükenme, Duyarsızlaşma ve Kişisel Başarı alt ölçeklerine ilişkin tükenmişlik düzeyleri üzerindeki etkisinin anlamsız olduğu bulunmuştur. Rehber öğretmenlerin mesleki tükenmişlik düzeylerinde cinsiyetleri, yaşları, medeni durumları ve hizmet verdikleri eğitim kademesinin (okul öncesi-ilkokul) ortak etkisine bağlı olarak ise anlamlı bir farklılık bulunmamıştır.

\footnotetext{
*Yrd. Doç. Dr., Yüzüncü Y1l Üniversitesi Eğitim Fakültesi Okul Öncesi Eğitimi Anabilim Dalı, ramazansak06@gmail.com, Tuşba/Van

**Yrd. Doç. Dr., Yüzüncü Yıl Üniversitesi Eğitim Fakültesi Okul Öncesi Eğitimi Anabilim Dalı, ikbalsahin@gmail.com, Tuşba/Van

***Rehber Öğretmen, Diyarbakır İl Milli Eğitim Müdürlüğü, dalcicek21@hotmail.com, Diyarbakır
} 
http://dx.doi.org/10.23891/efdyyu.2017.9

ISSN:1305-020

Anahtar Kavramlar: Rehber öğretmen, tükenmişlik, okul öncesi eğitim kurumu, ilkokul.

\section{Counselor Burnout: A Comparison across Preschool Institutions and Primary Schools}

Abstract: The aim of this study is to compare school counselors' experiences of burnout across two types of working environment. The sample for this survey-based research comprised 215 counselors, 72 working in preschool institutions and 143 in primary schools. Data were collected using a Demographic Information Form designed by the researchers and Maslach Burnout Inventory, and analyzed through independent samples t-tests and two-way ANOVAs. Data analysis established that there was a statistically significant difference in the respondents' Emotional Exhaustion sub-scales, according to the educational level of the children they worked with. Specifically, those counselors working in primary schools were more susceptible to burnout than those working in preschools there were no statistically significant differences in burnout level associated with the respondents' gender, age, or marital status in any of the sub-scales (i.e., Emotional Exhaustion, Depersonalization and Personal Accomplishment); nor was there any statistically significant interaction effect of school type with the counselors' gender, age or marital status.

Key Words: Counselor, job satisfaction, preschool institution, primary school.

\section{Giriş}

Eğitim-öğretim sürecinde öğretmenlerin performanslarını ve öğrencileriyle ilişkilerini belirleyen önemli bir olgu olan mesleki tükenmişlik (Maslach, 2006), eğitim alanındaki 
araştırmaların önemli konularından birini oluşturmaktadır. Tükenmişlik kavramı her ne kadar işle ilgili stres semptomlarını kapsayan bir sendrom olarak ilk kez Freudenberger (1974) tarafından açıklanmış olsa da, ilgili alan yazında Maslach ve meslektaşlarının çalışmalarının, tükenmişliğin psikolojik bir olgu olarak deneysel çalışmaların temelini oluşturduğu kabul edilmektedir (Bardhoshi, Schweinle ve Duncan, 2014). Freudenberger (1974) tarafindan tükenmişliğin sözlük anlamı, kişinin enerji, güç ya da çeşitli kaynaklarına aşırı yüklenilmesi sonucu ortaya çıkan bitkinlik, yorgunluk ve başarısızlık hissi şeklinde açıklanmıştır. Bununla birlikte mesleki tükenmişliği, bireylerin mesleklerinin özgün anlam ve amacından kopmaları, hizmet verdikleri bireylerle artık ilgilenememeleri ya da aşırı stres ve doyumsuzluğa bağlı olarak bireylerin kendilerini psikolojik olarak mesleklerinden geri çekmeleri olarak tanımlamak mümkündür (Kaçmaz, 2005). Maslach, Schaufeli ve Lieter'e (2001) göre ise mesleki tükenmişlik; bireylerin iş yaşamlarında, uzun süreli ve devamlı olarak duygusal ve kişiler arası stres yaratıcılara maruz kalmalarıdır.

Mesleki tükenmişliğin farklı tanımları yapılıyor olsa da, bu kavramla ilişkili üç temel boyut bulunmaktadır. Bunlardan birincisi, bu karmaşık sendromun en bariz belirtisi olarak görülen, tükenmişliktir (Duygusal Tükenme). İkincisi, işten kopmaya ilişkin hisler (duyarsızlaşma), üçüncüsü ise etkisizlik duygusu ve başarı eksikliğidir (Maslach, Schaufeli ve Leiter, 2001). Birinci alt boyut olarak kabul edilen duygusal tükenme, insanlarla temas halinde olan mesleklerde daha fazla görülmektedir. Duygusal tükenmenin başlamasıyla iş hayatında duygular egemen olmaya başlamakta ve diğer bireylerin duygusal isteklerinden etkilenilmektedir (Maslach, 1982). Duygusal tükenme, artan iş taleplerine karşı bir tepki olarak geliştirilmekte, bireyde aşırı yük duygusu yaratarak hizmet verilenlerin katılımıyla kişinin kapasitesini tüketmektir (Lee ve Ashforth, 1996). Duygusal tükenme hem duygusal 
olarak hem de fiziksel olarak enerji kaybına sebep olmaktadır (Maslach ve Leiter, 1997). Duyarsızlaşma boyutu ise tükenmişliğin kişilerarası boyutunu temsil etmektedir. Duyarsızlaşma, hizmet verilen bireylerin ihtiyaçlarına cevap veremediğini hissetme ve yaptığ1 işten duygusal ve bilişsel olarak amaçlı bir şekilde uzaklaşmayı ifade etmektedir. Bir başka ifadeyle, bireyin kendisi ve hizmet verdiği bireyler arasına mesafe koyma çabası duyarsızlaşma olarak tanımlanmaktadır. Üçüncü boyut olan kişisel başarı boyutu ise tükenmişliğin öz-değerlendirme boyutudur ve iş yerinde beceriksizlik, başarısızlık ve verim eksikliğine işaret etmektedir (Maslach, Schaufeli ve Leiter, 2001).

Öğrenci kişilik hizmetleri kapsamında sunulan hizmetlerden biri olan rehberlik (Yeşilyaprak, 2006), bireyin sağlıklı bir biçimde gelişebilmesi, istenilen davranış ve uyumu gösterebilmesi için gerekli yorum yapma, planlama ve karar verme süreçlerinde bireye ihtiyaç duyacağı bilgi ve beceriyi kazanabilmesi yolunda uzmanlar tarafından sunulan yardım sürecidir (Vural, 2004). Okul öncesi eğitim kurumlarında ve ilkokul kademesinde sağlanan rehberlik hizmetleri genel olarak; öğrencinin kendisi, öğretmeni/öğretmenleri ve ailesi tarafından yetenek, beceri ve diğer özelliklerinin fark edilmesini amaçlamaktadır. Bununla birlikte, bu kademelerde sunulan rehberlik hizmetleri, öğrencinin yetiştiği ortamın iyileştirilmesine, bireysel ve sosyal gelişiminin desteklenmesine, etkili öğrenme ve çalışma becerisi ile motivasyonunun artırılmasına yöneliktir (MEB, 2001).

Türkiye'de Milli Eğitim Bakanlığı (MEB) tarafından 2012 yılına kadar okul öncesi eğitim kurumları dışındaki tüm kademelere rehber öğretmen atanması yapılmaktaydı. 2012 yılına gelindiğinde, rehber öğretmenler ilk kez okul öncesi eğitim kurumlarına atanmaya başlanmıştır. 2013 yılında atamalar devam etmesine rağmen 2014 yılında bu uygulamaya Danıştay tarafından son verilmiş ve bu kurumlardaki rehber öğretmen norm kadrosu da 
kapatılmıştır. MEB tarafından 2015 yılında okul öncesi eğitim kurumlarına tekrar rehber öğretmen kadrosu açılıp atamaların yapılmasıyla birlikte, bir kez daha okul öncesi eğitim kurumlarında rehberlik hizmetleri sunulmaya başlanmıştır. Ancak, 25.11.2016 tarihli resmi gazetede yayımlanan MEB'in Norm Kadro Yönetmeliğindeki değişiklik ile anaokullarındaki rehber öğretmen norm kadrosu tekrar kaldırılmış (Resmi Gazete, 2016); 2017 yılı bahar döneminden itibaren okul öncesi eğitim kurumlarındaki rehber öğretmenlerin diğer kademelerde görevlendirilecekleri ifade edilmiştir. Ancak söz konusu değişikliğin tekrar iptali de ihtimal dâhilindedir. Rehber öğretmen atamalarına ilişkin yaşanan bu değişken süreç, okul öncesi eğitim kurumlarında sağlanan rehberlik hizmetleri ile ilgili çalışmaların yapılmasını gerekli kılmaktadır. Ancak, alan yazında Türkiye'de okul öncesi eğitim kurumlarında görev yapan rehber öğretmenlere ilişkin çalışmaların oldukça az ve yetersiz olduğu görülmektedir (Dalçiçek, 2016; Eren, 2014; Kardeş, 2014; Yerlikaya, Sak ve Şahin Sak, 2014). Özellikle okul öncesi eğitim kurumalarında çalışan rehber öğretmenlerin mesleki doyum ve mesleki tükenmişliklerinin incelenmesi konusu bu alanda ciddi bir eksiklik olarak düşünülmektedir.

Okul öncesi eğitim kurumlarında rehber öğretmenlerin görevlendirilmesine karar verilmesi, en çok bu kademede göreve başlayan rehber öğretmenleri etkilemektedir. Çünkü daha üst eğitim kademelerinde göreve başlayacaklarına ilişkin beklentileri olan rehber öğretmenlerin okul öncesi eğitim kurumlarında çalışmaya başlamaları, birtakım güçlükler yaşamaları ihtimalini doğurmaktadır. Gerek lisans eğitimleri süresince okul öncesi eğitim kademelerindeki rehberlik hizmetleri konusunda neredeyse hiç ders almamalarının, gerekse okul öncesi eğitim kurumlarındaki görevleri süresince rehberlik dışı işlerde çalıştırılmalarının bu kademede görev yapan rehber öğretmenleri olumsuz etkilediği düşünülmektedir (Dalçiçek, 2016). Özellikle, danışmanlık dışındaki görevlerin rehber öğretmenler için tükenmişliğin 
yordayıcısı olduğu kabul edilmektedir (Bardhoshi, Schweinle ve Duncan, 2014). Bu bağlamda, okul öncesi eğitim kademesinde görev yapan rehber öğretmenlerin mesleki tükenmişlik düzeyleri, bu kademede sunulan rehberlik hizmetlerinin niteliği açısından önemli bir belirleyicidir. Bununla birlikte, okul öncesi eğitim kademesi ve bu kademeye en yakın olan ilkokul kademesinde görev yapan rehber öğretmenlerin mesleki tükenmişliklerinin karşılaştırılmasının, okul öncesi eğitim kademesinde çalışan rehber öğretmenlerin mesleki tükenmişlikleri hakkında daha gerçekçi bir fikir vermesi açısından önemli olduğu düșünülmektedir.

İlgili alan yazın incelendiğinde öğretmenlerin mesleki tükenmişliklerini konu alan çeşitli çalışmaların olduğu görülmektedir (Acun, 2010; Amasralı, 2016; Arı, 2015; Aslan, 2009; Başol ve Altay, 2009; Baydar, 2013; Bayrakdar, 2014; Çolakoğlu, 2014; Diri ve Kıral, 2016; Erdemoğlu-Şahin, 2007; Erkul, 2014; Khezerlou, 2012; Koralay, 2014; Seferoğlu, Yıldız ve Avcı Yücel, 2012; Şahin ve Şahin, 2013; Tunaboylu, 2015; Turtulla, 2014; Uğuz, 2016; Yoğun-Erçen, 2007). Bazı çalışmalar okul öncesi öğretmenlerinin mesleki tükenmişliklerini ele alırken (Akman, Taşkın, Özden ve Çörtü, 2010; Ertürk, 2012; Gürbüz, 2008), bazıların da okul yöneticilerinin tükenmişlik düzeyleri incelenmiştir (Çatır, 2014; Özyürek, Gümüş ve Doğan, 2012; Yıldırım, 2009). Bazı çalışmalar ise tükenmişlikle birlikte mesleki doyum, stres gibi başka değişkenleri birlikte ele almıştır (Gündoğdu, 2013, Yalçın, 2013). Ayrıca, rehber öğretmenlerin mesleki tükenmişlikleri (Akten, 2007; Aydemir, 2014; Böşören, 2005; Seçer, 2011; Umay, 2015) ve lisede görev yapan rehber öğretmenler (Belgi, 2016) veya ilköğretim/ortaöğretim kurumlarında görev yapan rehber öğretmenler (Yıldız, 2011) gibi farklı kademelerde görev yapan rehber öğretmenlerin mesleki tükenmişlikleri de çeşitli çalışmaların konusu olmuştur. Daha önce yapılmış çalışmalar genel olarak 
http://dx.doi.org/10.23891/efdyyu.2017.9

ISSN:1305-020

değerlendirildiğinde, okul öncesi eğitim kurumlarında görev yapan rehber öğretmenler ile ilkokul kademesinde görev yapan rehber öğretmenlerin mesleki tükenmişliklerini konu alan bir çalışmaya rastlanılmamıştır.

Erken yaşlarda verilen eğitimin çocukların hayatlarındaki en kritik dönem olduğu (Tezel Şahin ve Sak, 2016) düşünüldüğünde, bu kademelerde sunulan rehberlik hizmetlerinin amacına ulaşmasında rehber öğretmenlerin hayati bir rolü olduğu ortadadır. Bununla birlikte sunulan hizmetin kalitesini belirleyen önemli unsurlardan biri olarak kabul edilen tükenmişlik, iş gücü, zaman ve emek kaybına, işten ayrılmalara ve hizmetin kalitesinin düşmesine sebep olabilmektedir. Buna paralel olarak, okul öncesi eğitim kurumlarında rehber öğretmenlerin görev alıp almayacaklarına ilişkin hızlı değişiklikler olurken, hali hazırda bu kademede görev yapan rehber öğretmenlerin mesleki tükenmişliklerinin ilkokul kademesindeki rehber öğretmenlerin tükenmişlikleriyle karşılaştırılmasının, özellikle okul öncesinde sunulan rehberlik hizmetleri hakkında da bir ipucu verebileceği düşünülmektedir.

$\mathrm{Bu}$ nedenle bu çalışmanın amacı, okul öncesi eğitim kurumlarında ve ilkokul kademesinde görev yapan rehber öğretmenlerin mesleki tükenmişliklerinin karşılaştırılmasıdır. Bu amaç doğrultusunda aşağıdaki araştırma sorularına cevap aranmıştır.

Rehber öğretmenlerin tükenmişlik düzeyleri hizmet verdikleri eğitim kademesine (okul öncesi-ilkokul) göre anlamlı bir farklılık göstermekte midir?

Rehber öğretmenlerin mesleki tükenmişlik düzeyleri, cinsiyet ve hizmet verdikleri eğitim kademesinin (okul öncesi-ilkokul) ortak etkisine bağlı olarak anlamlı bir farklılık göstermekte midir?

Rehber öğretmenlerin mesleki tükenmişlik düzeyleri, yaş ve hizmet verdikleri eğitim kademesinin (okul öncesi-ilkokul) ortak etkisine bağlı olarak anlamlı bir farklılık göstermekte 
http://dx.doi.org/10.23891/efdyyu.2017.9

ISSN:1305-020

midir?

Rehber öğretmenlerin mesleki tükenmişlik düzeyleri, medeni durum ve hizmet verdikleri eğitim kademesinin (okul öncesi-ilkokul) ortak etkisine bağlı olarak anlamlı bir farkl111k göstermekte midir?

\section{Yöntem}

Araştırmanın Modeli: Bu çalışmada okul öncesi eğitim kurumlarında ve ilkokul kademesinde görev yapan rehber öğretmenlerin mesleki tükenmişlikleri karşılaştırıldığından, çalışma, tarama modelinde betimsel bir çalışmadır. Tarama çalışmalarında evrenden seçilen örneklemden elde edilen veriler kullanılarak evrenin eğilim, tutum ve görüşleri nicel veya sayısal olarak tanımlanmakta (Creswell, 2013); örneklemden elde edilen bulgular kullanılarak evrene ilişkin genellemede bulunulmaya çalışılmaktadır (Fraenkel ve Wallen, 2006). Bu çalışmada örneklem olarak seçilen rehber öğretmenlerin mesleki tükenmişlikleri incelenerek evreni oluşturan rehber öğretmenlerin mesleki tükenmişlerine ilişkin genellemede bulunulmaya çalışılmaktadır.

Araştırmanın Örneklemi: Çalışmanın örneklemini, Doğu ve Güney Doğu Anadolu bölgelerinden basit seçkisiz örnekleme yöntemiyle seçilen ve okul öncesi eğitim kurumlarında görev yapan 72 rehber öğretmen ve ilkokul kademesinde görev yapan 143 rehber öğretmen olmak üzere toplamda 215 rehber öğretmen oluşturmaktadır.

Tablo 1. Çalışmaya katılan rehber ögretmenlerin demografik özelliklerine ilişkin bilgiler

\begin{tabular}{llll}
\hline Kademe & Cinsiyet & n & \% \\
\hline \multirow{2}{*}{ Okul öncesi } & Kadın & 35 & 48.6 \\
\cline { 2 - 4 } & Erkek & 37 & 51.4 \\
\hline \multirow{2}{*}{ Ilkokul } & Kadın & 83 & 58.0 \\
\cline { 2 - 4 } & Erkek & 60 & 42.0 \\
\hline \multirow{2}{*}{ Okul öncesi } & Yaş & $\mathbf{n}$ & $\mathbf{\%}$ \\
& 25 ve altı & 34 & 47.2 \\
\cline { 2 - 4 } & 26-30 arası & 24 & 33.3 \\
\cline { 2 - 4 } & 31 ve üstü & 14 & 19.4 \\
\hline
\end{tabular}


http://dx.doi.org/10.23891/efdyyu.2017.9

ISSN:1305-020

\begin{tabular}{|c|c|c|c|}
\hline \multirow[t]{4}{*}{ İlkokul } & 25 ve alt1 & 43 & 33.6 \\
\hline & 26-30 aras1 & 48 & 34.0 \\
\hline & 31 ve üstü & 52 & 36.4 \\
\hline & Medeni durum & $\mathbf{n}$ & $\%$ \\
\hline \multirow{2}{*}{ Okul öncesi } & Evli & 34 & 47.2 \\
\hline & Bekâr & 38 & 52.8 \\
\hline \multirow{3}{*}{ İlkokul } & Evli & 85 & 59.4 \\
\hline & Bekâr & 58 & 40.6 \\
\hline & Mezun olunan bölüm & $\mathbf{n}$ & $\%$ \\
\hline \multirow{2}{*}{ Okul öncesi } & PDR & 66 & 91.7 \\
\hline & Diğer & 6 & 8.3 \\
\hline \multirow{3}{*}{ İlkokul } & PDR & 110 & 76.9 \\
\hline & Diğer & 33 & 23.1 \\
\hline & Eğitim durumu & $\mathbf{n}$ & $\%$ \\
\hline \multirow{2}{*}{ Okul öncesi } & Lisans & 67 & 93.1 \\
\hline & Lisansüstü & 5 & 6.9 \\
\hline \multirow{2}{*}{ İlkokul } & Lisans & 126 & 88.1 \\
\hline & Lisansüstü & 17 & 11.9 \\
\hline & Mesleki deneyim & $\mathbf{n}$ & $\%$ \\
\hline \multirow{4}{*}{ Okul öncesi } & $0-5$ y1l & 55 & 76.4 \\
\hline & $6-10$ yil & 7 & 9.7 \\
\hline & $11-15$ y1l & 4 & 5.6 \\
\hline & 16 ve üstü yıl & 6 & 8.3 \\
\hline \multirow{4}{*}{ İlkokul } & $0-5$ y1l & 89 & 62.2 \\
\hline & $6-10$ y1l & 19 & 13.3 \\
\hline & $11-15$ y1l & 20 & 14.0 \\
\hline & 16 ve üstü yıl & 15 & 10.5 \\
\hline
\end{tabular}

Tablo 1 incelendiğinde, okul öncesi eğitim kademesinde görev yapan rehber öğretmenlerden 35'inin (\%48.6) kadın, 37’sinin (\%51.4) erkek olduğu, ilkokul kademesinde görev yapan rehber öğretmenlerden ise 83’ünün (\%58) kadın, 60’ının (\%42) ise erkek olduğu görülmektedir. Katılımcıların yaş dağılımı incelendiğinde, okul öncesi eğitim kademesinde görev yapan rehber öğretmenlerden 34'ü (\%47.2) 25 ve altı yaş aralığında, 24'ü (\%33.3) 2630 yaş aralığında ve 14 'ü (\%19.4) 31 ve üstü yaş aralığında, ilkokul kademesinde görev yapan rehber öğretmenlerden ise 43’ü (\%33.6) 25 ve altı yaş aralığında, 48’i (\%34.0) 26-30 yaş aralığında ve 52'si (\%36.4) 31 ve üstü yaş aralığındadır.

Katılımcıların medeni durumları ile ilgili olarak, okul öncesi eğitim kademesinde görev yapan rehber öğretmenlerden 34'ünün (\%47.2) bekar, 38'inin (\%52.8) evli, ilkokul 
kademesinde görev yapan rehber öğretmenlerden ise 85'inin (\%59.4) evli, 58'inin (\%40.6) bekar olduğu görülmektedir. Rehber öğretmenlerin mezun oldukları bölümlere ve eğitim durumlarına bakıldığında, okul öncesi eğitim kademesinde görev yapan rehber öğretmenlerden 66’sı (\%91.7) PDR bölümünden, 6’s1 (\%8.3) PDR dışındaki bölümlerinden; ilkokul kademesinde görev yapan rehber öğretmenlerden ise 110’u (\%76.9) PDR bölümünden, 33’ü (\%23.1) PDR dışındaki bölümlerden mezun olmuştur. Bununla birlikte, okul öncesi eğitim kademesinde görev yapan rehber öğretmenlerden 5'i (\%6.9) lisansüstü eğitim almışken, ilkokul kademesinde görev yapan rehber öğretmenlerden 17'si (\%11.9) lisansüstü eğitim almıştır.

Hem okul öncesi eğitim kademesinde görev yapan rehber öğretmenlerin çoğunluğu (\%76.4), hem de ilkokul kademesinde görev yapan rehber öğretmenlerin çoğunluğu (\%62.2) 0-5 yıl arası mesleki deneyime sahiptir. Ayrıca, okul öncesi eğitim kurumlarında görev yapan rehber öğretmenlerin tamamının çalıştıkları okuldaki çocuk sayısı 500'ün altındayken, ilkokul kademesinde görev yapan rehber öğretmenlerin çalıştıkları öğrenci sayısı 500 ile 1500 arasında değişmektedir.

Veri Toplama Araçları: $\mathrm{Bu}$ çalışmada veri toplama aracı olarak araştırmacılar tarafından hazırlanan Kişisel Bilgi Formu ve Christina Maslach (1981) tarafından geliştirilen ve Ergin (1992) tarafindan Türkçeye uyarlanan Maslach Tükenmişlik Envanteri kullanılmıştır. Maslach Tükenmişlik Envanteri, üç alt boyut ve toplamda 22 maddeden oluşmaktadır. Duygusal Tükenme alt boyutu 9 maddeden $(1,2,3,6,8,13,14,16,20)$, Duyarsızlaşma alt boyutu 5 maddeden $(5,10,11,15,22)$ ve Kişisel Başarı alt boyutu 8 maddeden $(4,7,9,12,17,18,19,21)$ oluşmaktadır. Ölçeğin Duygusal Tükenme alt boyutu 
güvenirlik katsayısı .90, Duyarsızlaşma alt boyutu güvenirlik katsayısı .79 ve Kişisel Başarı alt boyutu güvenirlik katsayısı .71 olarak hesaplanmıştır.

Ölçek likert tipi olup her bir madde için katılımcıların 0-4 arasında bir tercih yapmaları istenmektedir. Duygusal Tükenme ve Duyarsızlaşma alt ölçeklerindeki maddeler bu şekilde puanlanırken, Kişisel Başarı alt ölçeğindeki maddeler ters puanlanmaktadır. Maslach Tükenmişlik Envanterinin alt ölçeklerinden alınabilecek puanlar şu şekilde değerlendirilmektedir: Duygusal Tükenme alt ölçeğinden 28 ve üzeri puan alınması yüksek tükenmişlik, 22-27 aralığında puan alınması normal tükenmişlik ve 0-21 aralığında puan alınması ise düşük düzeyde tükenmişlik olarak kabul edilmektedir. Duyarsızlaşma alt ölçeğinden 15 ve üzeri puan almak yüksek tükenmişlik, 12-14 aralığında puan almak normal düzeyde tükenmişlik ve 0-11 aralığında puan almak ise düşük düzeyde tükenmişlik olarak değerlendirilmektedir. Kişisel Başarı alt ölçeğinden 0-26 aralığında puan almak yüksek tükenmişlik, 27-32 aralığında puan almak normal düzeyde tükenmişlik, 32 ve üzeri puan almak ise düşük düzeyde tükenmişlik olarak kabul edilmektedir.

Verilerin Toplanması: Araştırmanın verilerinin toplanabilmesi için öncelikle Milli Eğitim Bakanlığından, Doğu ve Güneydoğu Anadolu Bölgelerinde ölçme araçlarının kullanılabilmesi için gerekli izinler alınmıştır. Daha sonra alınan izin belgeleriyle birlikte okullara gidilmiş; gerekli bilgilendirmeler yapıldıktan sonra çalışmaya gönüllü katılmak isteyen öğretmenlere veri toplama araçları bırakılmış ve bir haftalık süre içinde doldurmaları istenmiştir. Bir haftanın sonunda veri toplama araçları geri toplanmıştır.

Verilerin Analizi: Toplanan veri toplama araçları cevapsız bırakılma ya da birden çok işaretleme yapılması bağlamında gözden geçirilmiş, eksikleri bulunan 35 ölçek 
değerlendirmeye alınmamıştır. Veriler bilgisayar ortamında istatistik programı yardımıyla analiz edilmiştir. Öncelikle, toplanan verilerin normal dağılım gösterip göstermediğini test etmek için Kolmogorow-Smirnow testi kullanılmıştır. Bu testin sonucuna göre, Maslach Tükenmişlik Envanterinin üç alt boyutunda da ölçekten elde edilen puanların normal dağılım gösterdiği ( $\mathrm{n}=223, \mathrm{p}>.05)$ bulunmuştur. Bu nedenle verilerin analizinde iki gruptan oluşan değişkenler için bağımsız örneklemler için t testi ve iki bağımsız değişkenin bir bağımlı değişken üzerindeki etkisini test etmek için ise bağımsız gruplar için iki yönlü ANOVA parametrik testleri kullanılmıştır. Analizlerde anlamlılık düzeyi .05 olarak kabul edilmiştir.

\section{Sonuçlar}

\section{Rehber öğretmenlerin tükenmişlik düzeyleri hizmet verdikleri eğitim kademesine (okul} öncesi ve ilkokul) göre anlamlı bir farklılık göstermekte midir?

Tablo 2. Mesleki tükenmişlik envanteri alt ölçek puanlarının hizmet verilen eğitim kademesine göre t-testi sonuçları

\begin{tabular}{|c|c|c|c|c|c|c|c|}
\hline Alt Ölçekler & Eğitim Kademesi & $\mathbf{N}$ & $\overline{\mathbf{x}}$ & S.s & $\mathbf{t}$ & $\mathbf{p}$ & $\eta^{2}$ \\
\hline \multirow[b]{2}{*}{ Duygusal Tükenme } & Okul öncesi & 72 & 7.45 & 4.84 & \multirow[b]{2}{*}{-2.566} & \multirow[b]{2}{*}{.011} & \multirow[b]{2}{*}{.37} \\
\hline & İlkokul & 143 & 9.53 & 5.93 & & & \\
\hline \multirow{2}{*}{ Duyarsızlaşma } & Okul öncesi & 72 & 1.37 & 2.13 & \multirow{2}{*}{-1.115} & \multirow{2}{*}{.266} & \multirow{2}{*}{.16} \\
\hline & İlkokul & 143 & 1.81 & 2.95 & & & \\
\hline \multirow{2}{*}{ Kişisel Başar1 } & Okul öncesi & 72 & 8.00 & 3.31 & \multirow{2}{*}{.613} & \multirow{2}{*}{.540} & \multirow{2}{*}{.09} \\
\hline & İlkokul & 143 & 7.65 & 4.11 & & & \\
\hline
\end{tabular}

Okul öncesi eğitim kurumlarında ve ilkokul kademesinde görev yapan rehber öğretmenlerin mesleki tükenmişliklerinin, hizmet verdikleri eğitim kademesine göre farklılaşıp farklılaşmadığını belirlemek için yapılan bağımsız örneklemler için $\mathrm{t}$ testi sonucunda, aradaki farkın Duygusal Tükenme alt ölçeğinde ilkokul kademesindeki rehber öğretmenler lehinde anlamlı olduğu bulunmuştur $\left(\mathrm{t}_{213}=-2.566, \mathrm{p}<.05\right)$. Duyarsılaşma alt ölçeği $\left(\mathrm{t}_{213}=-1.115, \mathrm{p}>.05\right)$ ve Kişisel Başarı alt ölçeğinde $\left(\mathrm{t}_{213}=-.613, \mathrm{p}>.05\right)$ ise anlamlı bir 
fark bulunmamıştır. Tablo 2 incelendiğinde, ilkokullarda görev yapan rehber öğretmenlerin ortalamalarının 9.53, okul öncesi eğitim kurumlarında görev yapan rehber öğretmenlerin ortalamalarının ise 7.45 olduğu görülmektedir. Bu nedenle ilkokullarda görev yapan rehber öğretmenlerin mesleki tükenmişliklerinin, Duygusal Tükenme alt ölçeğinde, okul öncesi eğitim kurumlarında görev yapan rehber öğretmenlerin mesleki tükenmişliklerinden daha yüksek olduğunu söylemek mümkündür. Bununla birlikte, rehber öğretmenlerin mesleki tükenmişliklerinin Duygusal Tükenme boyutunda, eğitim verdikleri kademeye göre bulunan farka ilişsin etki büyüklüğü orta düzeydedir $\left(\eta^{2}=.37\right)($ Cohen, 1988).

Rehber öğretmenlerin mesleki tükenmişlik düzeyleri, cinsiyet ve hizmet verdikleri eğitim kademesinin (okul öncesi-ilkokul) ortak etkisine bağlı olarak anlamlı bir farklılık göstermekte midir?

Tablo 3. Eğitim kademesi ve cinsiyete göre mesleki tükenmişlik envanteri alt ölçek puanlarına ilişkin iki yönlü ANOVA sonuçlart

\begin{tabular}{|c|c|c|c|c|c|c|c|}
\hline Alt Ölçekler & $\begin{array}{l}\text { Varyansın } \\
\text { Kaynağı }\end{array}$ & $\begin{array}{l}\text { Kareler } \\
\text { toplamı }\end{array}$ & Sd & $\begin{array}{c}\text { Kareler } \\
\text { ortalaması }\end{array}$ & $\mathbf{F}$ & $\mathbf{p}$ & $\eta^{2}$ \\
\hline \multirow{4}{*}{$\begin{array}{l}\text { Duygusal } \\
\text { Tükenme }\end{array}$} & Cinsiyet & 48.447 & 1 & 48.447 & 1.554 & .214 & .007 \\
\hline & Eğitim kademesi & 199.572 & 1 & 199.572 & 6.401 & .012 & .029 \\
\hline & $\begin{array}{l}\text { Cinsiyet }{ }^{*} \text { Eğitim } \\
\text { kademesi }\end{array}$ & 57.394 & 1 & 57.394 & 1.841 & .176 & .009 \\
\hline & Hata & 6579.097 & 211 & 31.181 & & & \\
\hline \multirow{4}{*}{ Duyarsızlaşma } & Cinsiyet & .643 & 1 & .643 & .087 & .768 & .000 \\
\hline & Eğitim kademesi & 8.998 & 1 & 8.998 & 1.217 & .271 & .006 \\
\hline & $\begin{array}{l}\text { Cinsiyet }{ }^{*} \text { Eğitim } \\
\text { kademesi }\end{array}$ & 1.134 & 1 & 1.134 & .153 & .696 & .001 \\
\hline & Hata & 1559.405 & 211 & 7.391 & & & \\
\hline \multirow{4}{*}{ Kişisel Başarı } & Cinsiyet & 9.159 & 1 & 9.159 & .609 & .436 & .003 \\
\hline & Eğitim kademesi & 5.088 & 1 & 5.088 & .338 & .561 & .002 \\
\hline & $\begin{array}{l}\text { Cinsiyet* Eğitim } \\
\text { kademesi }\end{array}$ & 7.387 & 1 & 7.387 & .491 & .484 & .002 \\
\hline & Hata & 3171.630 & 211 & 15.031 & & & \\
\hline
\end{tabular}

Tablo 3 incelendiğinde, cinsiyetin $\left(\mathrm{F}_{(1,211)}=1.554, \mathrm{p}>.05\right)$ rehber öğretmenlerin Duygusal Tükenme alt ölçeğine ilişkin tükenmişlik düzeyleri üzerindeki etkisinin anlamsız 
olduğu görülmektedir. Hizmet verilen eğitim kademesinin $\left(\mathrm{F}_{(1,211)}=6.401, \mathrm{p}<.05\right)$ ise rehber öğretmenlerin Duygusal Tükenme alt ölçeğine ilişkin tükenmişlik düzeyleri üzerindeki etkisinin anlamlı olduğu bulunmuştur. Ancak, Cinsiyet* Eğitim kademesinin ortak etkileri incelendiğinde, $\left(\mathrm{F}_{(1,211)}=1.841, \mathrm{p}>.05\right)$ sonucun anlamsız olduğu belirlenmiştir. Bu nedenle, rehber öğretmenlerin Duygusal Tükenme alt ölçeğine ilişkin tükenmişlik düzeyleri, hizmet verdikleri eğitim kademesi ile cinsiyetin ortak etkisine göre farklılaşmamaktadır.

Cinsiyetin $\left(\mathrm{F}_{(1,211)}=.087, \mathrm{p}>.05\right)$ rehber öğretmenlerin Duyarsızlaşma alt ölçeğine ilişkin tükenmişlik düzeyleri üzerindeki etkisinin anlamsız olduğu görülmektedir. Hizmet verilen eğitim kademesinin de $\left(\mathrm{F}_{(1,211)}=1.217, \mathrm{p}>.05\right)$ rehber öğretmenlerin Duyarsızlaşma alt ölçeğine ilişkin tükenmişlik düzeyleri üzerindeki etkisinin anlamsız olduğu bulunmuştur. Ayrıca, Cinsiyet * Eğitim kademesinin ortak etkileri incelendiğinde $\left(\mathrm{F}_{(1,211)}=.153, \mathrm{p}>.05\right)$ sonucun anlamsız olduğu belirlenmiştir. Bu nedenle, rehber öğretmenlerin Duyarsızlaşma alt ölçeğine ilişkin tükenmişlik düzeyleri, hizmet verdikleri eğitim kademesi ile cinsiyetin ortak etkisine göre farklılaşmamaktadır.

Cinsiyetin $\left(\mathrm{F}_{(1,211)}=.609, \mathrm{p}>.05\right)$ rehber öğretmenlerin Kişisel Başarı alt ölçeğine ilişkin tükenmişlik düzeyleri üzerindeki etkisinin anlamsız olduğu görülmektedir. Hizmet verilen eğitim kademesinin de $\left(\mathrm{F}_{(1,211)}=.338, \mathrm{p}>.05\right)$ rehber öğretmenlerin Kişisel Başarı alt ölçeğine ilişkin tükenmişlik düzeyleri üzerindeki etkisinin anlamsız olduğu bulunmuştur. Ayrıca, Cinsiyet ${ }^{*}$ Eğitim kademesinin ortak etkileri incelendiğinde $\left(\mathrm{F}_{(1,211)}=.491, \mathrm{p}>.05\right)$ sonucun anlamsız olduğu belirlenmiştir. Bu nedenle, rehber öğretmenlerin Kişisel Başarl alt ölçeğine ilişkin tükenmişlik düzeyleri, hizmet verdikleri eğitim kademesi ile cinsiyetin ortak etkisine göre farklılaşmamaktadır. 
http://dx.doi.org/10.23891/efdyyu.2017.9

ISSN:1305-020

Rehber öğretmenlerin mesleki tükenmişlik düzeyleri, yaş ve hizmet verdikleri eğitim kademesinin (okul öncesi-ilkokul) ortak etkisine bağlı olarak anlamlı bir farklılık göstermekte midir?

Tablo 4. Eğitim kademesi ve yaşa göre mesleki tükenmişlik envanteri alt ölçek puanlarına ilişkin iki yönlü ANOVA sonuçları

\begin{tabular}{|c|c|c|c|c|c|c|c|}
\hline Alt Ölçekler & Varyansın Kaynağı & $\begin{array}{c}\text { Kareler } \\
\text { toplamı }\end{array}$ & Sd & $\begin{array}{c}\text { Kareler } \\
\text { ortalaması }\end{array}$ & $\mathbf{F}$ & $\mathbf{p}$ & $\eta^{2}$ \\
\hline \multirow{4}{*}{$\begin{array}{l}\text { Duygusal } \\
\text { Tükenme }\end{array}$} & Eğitim kademesi & 207.233 & 1 & 207.233 & 6.530 & .011 & .030 \\
\hline & Yaş & 15.820 & 2 & 7.910 & .249 & .780 & .002 \\
\hline & Eğitim kademesi ${ }^{*}$ Yaş & 15.866 & 2 & 7.933 & .250 & .779 & .002 \\
\hline & Hata & 6632.649 & 209 & 31.735 & & & \\
\hline \multirow{4}{*}{ Duyarsızlaşma } & Eğitim kademesi & 12.707 & 1 & 12.707 & 1.709 & .193 & .008 \\
\hline & Yaş & 5.467 & 2 & 2.733 & .368 & .693 & .004 \\
\hline & Eğitim kademesi * Yaş & 3.819 & 2 & 1.909 & .257 & .774 & .002 \\
\hline & Hata & 1554.382 & 209 & 7.437 & & & \\
\hline \multirow{4}{*}{ Kişisel Başarı } & Eğitim kademesi & 6.113 & 1 & 6.113 & .406 & .525 & .002 \\
\hline & Yaş & 28.321 & 2 & 14.160 & .941 & .392 & .009 \\
\hline & Eğitim kademesi ${ }^{*}$ Yaş & .441 & 2 & .221 & .015 & .985 & .000 \\
\hline & Hata & 3145.829 & 209 & 15.052 & & & \\
\hline
\end{tabular}

Tablo 4 incelendiğinde, hizmet verilen eğitim kademesinin $\left(F_{(1,209)}=6.530, p<.05\right)$ rehber öğretmenlerin Duygusal Tükenme alt ölçeğine ilişkin tükenmişlik düzeyleri üzerindeki etkisinin anlamlı olduğu görülmektedir. Ancak, yaş değişkeninin $\left(\mathrm{F}_{(2,209)}=.249, \mathrm{p}>.05\right)$, rehber öğretmenlerin Duygusal Tükenme alt ölçeğine ilişkin tükenmişlik düzeyleri üzerindeki etkisinin anlamsız olduğu görülmektedir. Ayrıca, Yaş* Eğitim kademesinin ortak etkileri incelendiğinde $\left(\mathrm{F}_{(2,209)}=.250, \mathrm{p}>.05\right)$ sonucun anlamsız olduğu belirlenmişstir. $\mathrm{Bu}$ nedenle, rehber öğretmenlerin Duygusal Tükenme alt ölçeğine ilişkin tükenmişlik düzeyleri, hizmet verdikleri eğitim kademesi ile yaşlarının ortak etkisine göre farklılaşmamaktadır.

Hizmet verilen eğitim kademesinin $\left(\mathrm{F}_{(1,209)}=1.709, \mathrm{p}>.05\right)$, rehber öğretmenlerin Duyarsızlaşma alt ölçeğine ilişkin tükenmişlik düzeyleri üzerindeki etkisinin anlamsız olduğu bulunmuştur. Yaş değişkeninin de $\left(\mathrm{F}_{(2,209)}=.249, \mathrm{p}>.05\right)$ rehber öğretmenlerin Duyarsızlaşma 
alt ölçeğine ilişkin tükenmişlik düzeyleri üzerindeki etkisinin anlamsız olduğu görülmektedir. Ayrıca, Yaş* Eğitim kademesinin ortak etkileri incelendiğinde $\left(\mathrm{F}_{(2,209)}=.257, \mathrm{p}>.05\right)$ sonucun anlamsız olduğu belirlenmiştir. Bu nedenle, rehber öğretmenlerin Duyarsızlaşma alt ölçeğine ilişkin tükenmişlik düzeyleri, hizmet verdikleri eğitim kademesi ile yaşlarının ortak etkisine göre farklılaşmamaktadır.

Hizmet verilen eğitim kademesinin $\left(\mathrm{F}_{(1,209)}=.406, \mathrm{p}>.05\right)$ rehber öğretmenlerin Kişisel Başarı alt ölçeğine ilişkin tükenmişlik düzeyleri üzerindeki etkisinin anlamsız olduğu bulunmuştur. Yaş değişkeninin de $\left(\mathrm{F}_{(2,209)}=.941, \mathrm{p}>\right.$.05) rehber öğretmenlerin Kişisel Başarl alt ölçeğine ilişkin tükenmişlik düzeyleri üzerindeki etkisinin anlamsız olduğu görülmektedir. Ayrıca, Yaş* Ĕgitim kademesinin ortak etkileri incelendiğinde $\left(\mathrm{F}_{(2,209)}=.015, \mathrm{p}>.05\right)$ sonucun anlamsız olduğu belirlenmiştir. Bu nedenle, rehber öğretmenlerin Kişisel Başarı alt ölçeğine ilişkin tükenmişlik düzeyleri, hizmet verdikleri eğitim kademesi ile yaşlarının ortak etkisine göre farklılaşmamaktadır.

Rehber öğretmenlerin mesleki tükenmişlik düzeyleri, medeni durum ve hizmet verdikleri eğitim kademesinin (okul öncesi-ilkokul) ortak etkisine bağlı olarak anlamlı bir farklılık göstermekte midir?

Tablo 5. Eğitim kademesi ve medeni duruma göre mesleki tükenmişlik envanteri alt ölçek puanlarına ilişkin iki yönlü ANOVA sonuçları

\begin{tabular}{llcccccc}
\hline \multirow{2}{*}{ Alt Ölçekler } & $\begin{array}{l}\text { Varyansın } \\
\text { Kaynağı }\end{array}$ & $\begin{array}{l}\text { Kareler } \\
\text { toplamı }\end{array}$ & Sd & $\begin{array}{c}\text { Kareler } \\
\text { ortalaması }\end{array}$ & F & $\mathbf{p}$ & $\boldsymbol{\eta}^{\mathbf{2}}$ \\
\hline \multirow{3}{*}{$\begin{array}{l}\text { Duygusal } \\
\text { Tükenme }\end{array}$} & Eğitim kademesi & 202.182 & 1 & 202.182 & 6.407 & .012 & .029 \\
\cline { 2 - 8 } & Medeni Durum & .531 & 1 & .531 & .017 & .897 & .000 \\
\cline { 2 - 8 } & $\begin{array}{l}\text { Eğitim kademesi } \\
\text { Medeni Durum }\end{array}$ & .927 & 1 & .927 & .029 & .864 & .000 \\
\cline { 2 - 8 } & Hata & 6658.356 & 211 & 31.556 & & & .006 \\
\hline \multirow{2}{*}{ Duyarsızlaşma } & Eğitim kademesi & 9.281 & 1 & 9.281 & 1.256 & .264 & .006 \\
\cline { 2 - 8 } & Medeni Durum & .818 & 1 & .818 & .111 & .740 & .004 \\
\cline { 2 - 7 } & $\begin{array}{l}\text { Eğitim kademesi } \\
\text { Medeni Durum }\end{array}$ & .836 & 1 & .836 & .113 & .737 & .002 \\
\hline
\end{tabular}




\begin{tabular}{llcccccc}
\hline & Hata & 1559.520 & 211 & 7.391 & & & \\
\hline \multirow{5}{*}{ Kişisel Başarı } & Eğitim kademesi & 6.155 & 1 & 6.155 & .409 & .523 & .002 \\
\cline { 2 - 8 } & Medeni Durum & .020 & 1 & .020 & .001 & .971 & .000 \\
\cline { 2 - 8 } & $\begin{array}{l}\text { Eğitim kademesi } \\
\text { Medeni Durum }\end{array}$ & 4.656 & 1 & 4.656 & .309 & .579 & .001 \\
\cline { 2 - 8 } & Hata & 3179.230 & 211 & 15.067 & & & \\
\hline
\end{tabular}

Tablo 5 incelendiğinde, hizmet verilen eğitim kademesinin $\left(F_{(1,211)}=6.407, p<.05\right)$, rehber öğretmenlerin Duygusal Tükenme alt ölçeğine ilişkin tükenmişlik düzeyleri üzerindeki etkisinin anlamlı olduğu görülmektedir. Medeni durum değişkeninin $\left(\mathrm{F}_{(1,211)}=.017, \mathrm{p}>.05\right)$ ise rehber öğretmenlerin Duygusal Tükenme alt ölçeğine ilişkin tükenmişlik düzeyleri üzerindeki etkisinin anlamsız olduğu görülmektedir. Ayrıca, Medeni Durum*Eğitim kademesinin ortak etkileri incelendiğinde de $\left(\mathrm{F}_{(1,211)}=.029, \mathrm{p}>.05\right)$ sonucun anlamsız olduğu belirlenmiştir. $\mathrm{Bu}$ nedenle rehber öğretmenlerin Duygusal Tükenme alt ölçeğine ilişkin tükenmişlik düzeyleri, hizmet verdikleri eğitim kademesi ile medeni durumlarının ortak etkisine göre farklılaşmamaktadır.

Hizmet verilen eğitim kademesinin $\left(\mathrm{F}_{(1,211)}=1.256, \mathrm{p}>.05\right)$ rehber öğretmenlerin Duyarsızlaşma alt ölçeğine ilişkin tükenmişlik düzeyleri üzerindeki etkisinin anlamsız olduğu belirlenmiştir. Bununla birlikte, medeni durum değişkeninin de $\left(\mathrm{F}_{(1,211)}=.111, \mathrm{p}>.05\right)$ rehber öğretmenlerin Duyarsızlaşma alt ölçeğine ilişkin tükenmişlik düzeyleri üzerindeki etkisinin anlamsız olduğu görülmektedir. Ayrıca, Medeni Durum * Eğitim kademesinin ortak etkileri incelendiğinde $\left(\mathrm{F}_{(1,211)}=.113, \mathrm{p}>.05\right)$ sonucun anlamsız olduğu belirlenmiştir. Bu nedenle, rehber öğretmenlerin Duyarsızlaşma alt ölçeğine ilişkin tükenmişlik düzeyleri, hizmet verdikleri eğitim kademesi ile medeni durumlarının ortak etkisine göre farklılaşmamaktadır.

Hizmet verilen eğitim kademesinin $\left(\mathrm{F}_{(1,211)}=.409, \mathrm{p}>.05\right)$, rehber öğretmenlerin Kişisel Başarı alt ölçeğine ilişkin tükenmişlik düzeyleri üzerindeki etkisinin anlamsız olduğu 
bulunmuştur. Medeni durum değişkeninin de $\left(\mathrm{F}_{(1,211)}=.001, \mathrm{p}>.05\right)$ rehber öğretmenlerin Kişisel Başarı alt ölçeğine ilişkin tükenmişlik düzeyleri üzerindeki etkisinin anlamsız olduğu görülmektedir. Ayrıca, Medeni Durum * Eğitim kademesinin ortak etkileri incelendiğinde, $\left(\mathrm{F}_{(1,211)}=.309, \quad \mathrm{p}>.05\right)$ sonucun anlamsız olduğu belirlenmiştir. Bu nedenle rehber öğretmenlerin Kişisel Başarı alt ölçeğine ilişkin tükenmişlik düzeyleri, hizmet verdikleri eğitim kademesi ile medeni durumlarının ortak etkisine göre farklılaşmamaktadır.

\section{Tartışma}

Okul öncesi eğitim kurumlarında ve ilkokul kademesinde görev yapan rehber öğretmenlerin mesleki tükenmişlikleri hizmet verdikleri eğitim kademesine göre karşılaştırıldığında, sadece Duygusal Tükenme alt ölçeğinde ilkokul kademesindeki rehber öğretmenler lehinde anlamlı fark bulunmuştur. Bu bulgu, Başören'in (2005) ilköğretim ve lise kademesinde görev yapan rehber öğretmenlerin mesleki tükenmişliklerinin anlamlı bir farklılık göstermediğini ortaya koyduğu çalışmasının sonuçlarıyla kısmen paralellik göstermektedir. Ancak bu sonuç, Dalçiçek'in (2016) çalışmasının sonuçlarıyla çelişmektedir. Dalçiçek (2016) çalışmasında, okul öncesi eğitim kademesinde çalışan rehber öğretmenlerin yaklaşık yarısının, ilkokul kademesinde görev yapanların ise yaklaşık üçte birinin çalıştıkları kademenin mesleki doyumları üzerinde olumsuz bir etkisi olduğunu dile getirdiklerini belirtmiştir. Bu durumda, Dalçiçek'in (2016) çalışmasının bir sonucu olarak okul öncesi eğitim kurumlarında çalışan rehber öğretmenlerin mesleki tükenmişliklerinin daha yüksek çıkması beklenmiştir. Ancak, yapılan çalışma sonucunda Duyarsızlaşma ve Kişisel Başarı alt ölçeklerinde anlamlı bir fark çıkmamış ve Duygusal Tükenme boyutunda da beklenenin tersi bir sonuç bulunmuştur. İlkokul kademesinde görev yapan rehber öğretmenlerin Duygusal Tükenme alt ölçeğinde mesleki tükenmişliklerinin daha yüksek çıkmasında, hizmet verdikleri 
birey sayısının çok fazla olmasının etkili olduğu düşünülmektedir. Çünkü Duygusal Tükenme, artan iş taleplerine karşı geliştirilen bir tepki olup, aşırı yük duygusu yaratarak hizmet verilenlerin katılımıyla bireyin kapasitesini tüketmek şeklinde tanımlanmaktadır (Lee \& Ashforth, 1996). Bu tanıma paralel olarak ilkokul kademesinde görev yapan rehber öğretmenlerin hizmet verdikleri öğrenci sayısı, veli sayısı ve doldurulması gereken evraklar okul öncesi kademesindekilerle karşılaştırıldığında, ilkokul kademesindeki iş yükünün oldukça fazla olduğu görülmekte, bu durumun da bu bulgu üzerinde etkili olduğu düşünülmektedir.

Cinsiyet değişkeninin rehber öğretmenlerin Duygusal Tükenme, Duyarsızlaşma ve Kişisel Başarı alt ölçeklerine ilişkin tükenmişlik düzeyleri üzerindeki etkisinin anlamsız olduğu bulunmuştur. Bu bulgu ilgili alan yazındaki bazı çalışmalarla benzerlik gösterirken, bazılarıyla da çelişmektedir. Yapılan bazı çalışmalarda cinsiyetin öğretmenlerin mesleki tükenmişlikleri üzerinde anlamlı bir etkisinin olmadığı bulunmuştur (Acun, 2010; Akman, Taşkın, Özden ve Çörtü, 2010; Çolakoğlu, 2014; Koralay, 2014; Seğmenli, 2001; Şahin ve Şahin, 2013; Tunaboylu, 2015; Uğuz, 2016). Alan yazında özellikle rehber öğretmenlerle yapılan ve cinsiyetin mesleki tükenmişlik üzerinde anlamlı bir etkisi olmadığı sonuca varılan çalışmalar da bulunmaktadır (Aydemir, 2014; Başören, 2005; Seçer, 2011). Bu çalışmalar, cinsiyetin tükenmişliğin güçlü bir yordayıcısı olamayacağını belirten Maslach, Schaufeli ve Leiter'i de (2001) desteklemektedir.

Yapılan bazı çalışmalarda ise, cinsiyetin öğretmenlerin mesleki tükenmişlikleri üzerinde anlamlı bir etkisinin olduğu bulunmuştur (Aslan, 2009; Başol ve Altay, 2009; Diri ve Kıral, 2016; Yoğun-Erçen, 2007). Bazı çalışmalarda mesleki tükenmişliğin sadece bir boyutunda cinsiyet değişkeni anlamlı bir farklılık göstermiştir. Akten (2007) cinsiyet 
değişkeninin rehber öğretmenlerin duygusal tükenmişlik boyutunda anlamlı farklılık gösterdiğini bulmuştur. Erkul (2014) kadın öğretmenlerin erkek öğretmenlere oranla duygusal tükenme boyutunda daha fazla tükenmişlik yaşadıklarını belirlemiştir. Seferoğlu, Yıldız ve Avcı Yücel (2012) cinsiyet değişkeninin öğretmenlerin mesleki tükenmişliğin kişisel başarı boyutu üzerinde anlamlı etkisinin olduğunu ortaya koyarken, Amasralı (2016), erkek öğretmenlerin kadın öğretmenlerden duyarsızlaşma alt boyutunda daha fazla tükenmişlik gösterdiklerini bulmuştur. Ayrıca, rehber öğretmenlerle yapılan bazı çalışmalarda da cinsiyetin mesleki tükenmişlik üzerinde anlamlı bir etkisi olduğu bulunmuştur (Belgi, 2016; Umay, 2015; Y1ld1z, 2011).

Rehber öğretmenlerin yaşlarının, Duygusal Tükenme, Duyarsızlaşma ve Kişisel Başarı alt ölçeklerine ilişkin tükenmişlik düzeyleri üzerindeki etkisinin anlamsız olduğu bulunmuştur. $\mathrm{Bu}$ bulgu ilgili alan yazındaki bazı çalışmalarla paralellik gösterirken, bazılarıyla da çelişmektedir. Bazı çalışmalar yaş değişkeninin öğretmenlerin mesleki tükenmişlikleri üzerinde anlamlı bir etkisinin olmadığını belirtirken (Acun, 2010; Başol ve Altay, 2009; Koralay, 2014: Tunaboylu, 2015; Uğuz, 2016; Umay, 2015; Y1ldı, 2011), baz1 çalışmalarda ise yaş değişkeninin öğretmenlerin mesleki tükenmişlikleri üzerinde anlamlı bir farkl1lık gösterdiği bulunmuştur (Amasralı, 2016; Aslan, 2009; Gürbüz, 2008; Özyürek, Gümüş ve Doğan, 2012; Yoğun-Erçen, 2007). Bazı çalışmalarda da, yaş değişkeni alt ölçeklerin bazılarında anlamlı farklılık göstermiştir (Diri ve Kıral, 2016; Erdemoğlu Şahin, 2007; Seçer, 2011; Seğmenli, 2001). Çolakoğlu'nun (2014) çalışmasında öğretmenlerin yaşlarına göre Duygusal Tükenme ve Duyarsızlaşma alt ölçeklerinde anlamlı farklılık bulunmuşken, Kişisel Başarısızlık alt ölçeğinde anlamlı bir farklılık bulunmamıştır. Maslach, Schaufeli ve Leiter (2001) ise, 30-40 yaş aralığından daha genç olan bireylerde tükenmişliğin 
daha yoğun görüldüğünü belirtmişlerdir. Bu çalışmadaki katılımcıların yaşları göz önünde bulundurulduğunda hem okul öncesi eğitim kademesinde hem de ilkokul kademesinde görev yapan rehber öğretmenlerin çoğunluğu 30 yaşın altında olmalarına rağmen tükenmişlik düzeylerinde yaş değişkenine göre anlamlı bir farklılık bulunmamıştır.

Rehber öğretmenlerin medeni durumlarının, Duygusal Tükenme, Duyarsızlaşma ve Kişisel Başarı alt ölçeklerine ilişkin tükenmişlik düzeyleri üzerindeki etkisinin anlamsız olduğu bulunmuştur. Bu bulgu ilgili alan yazındaki bazı çalışmalarla benzerlik gösterirken, bazılarıyla da çelişmektedir. Yapılan bazı çalışmalarda medeni durumun öğretmenlerin mesleki tükenmişlikleri üzerinde anlamlı bir etkisinin olmadığı bulunmuştur (Acun, 2010; Akten, 2007; Aydemir, 2014; Erkul, 2014; Gürbüz, 2008; Seçer, 2011; Uğuz, 2016; Y1ldız, 2011). Bazı çalışmalarda ise, medeni durumlarına göre öğretmenlerin mesleki tükenmişliklerinde anlamlı bir farklılık olduğu belirlenmiştir (Amasralı, 2016; Aslan, 2009; Başol ve Altay, 2009; Başören, 2005; Koralay, 2014; Tunaboylu, 2015). Bununla birlikte alan yazında, medeni durumun bazı alt ölçeklerde anlamlı farklılık gösterdiği çalışmalarda bulunmaktadır (Çolakoğlu, 2014; Diri ve Kıral, 2016; Erdemoğlu-Şahin, 2007). Akman, Taşkın, Özden ve Çörtü (2010) medeni durum değişkeninin mesleki tükenmişliğin kişisel başarı alt boyutu üzerinde anlamlı bir farklılık gösterdiğini bulmuşlar, bekar öğretmenlerin tükenmişlik düzeylerinin evli öğretmenlerden daha yüksek olduğunu belirtmişlerdir.

Rehber öğretmenlerin mesleki tükenmişlik düzeyleri, hizmet verdikleri eğitim kademesi (okul öncesi-ilkokul) ile cinsiyet, yaş ve medeni durumun değişkenlerinin ortak etkisine bağlı olarak Duygusal Tükenme, Duyarsızlaşma ve Kişisel Başarı alt ölçeklerinde anlamlı bir farklılık göstermemiştir. $\mathrm{Bu}$ nedenle gerek okul öncesi eğitim kurumlarında gerekse ilkokul kademesinde görev yapan rehber öğretmenlerin cinsiyetleri, yaşları ve medeni 
http://dx.doi.org/10.23891/efdyyu.2017.9

ISSN:1305-020

durumları bağlamında mesleki tükenmişlik düzeylerinin benzer olduğunu söylemek mümkündür.

\section{Sonuç ve Öneriler}

Okul öncesi eğitim kurumlarında ve ilkokul kademesinde görev yapan rehber öğretmenlerin mesleki tükenmişlikleri, hizmet verdikleri eğitim kademesine (okul öncesiilkokul) göre Duygusal Tükenme alt ölçeğinde anlamlı bir farklılık göstermişken, Duyarsızlaşma ve Kişisel Başarı alt ölçeklerinde anlamlı bir farklılık göstermemiştir. Diğer bir ifadeyle, ilkokullarda görev yapan rehber öğretmenlerin mesleki tükenmişlikleri Duygusal Tükenme alt ölçeğinde okul öncesi eğitim kurumlarında görev yapan rehber öğretmenlerin mesleki tükenmişliklerinden daha yüksektir.

Cinsiyet, yaş ve medeni durum değişkenlerinin rehber öğretmenlerin Duygusal Tükenme, Duyarsızlaşma ve Kişisel Başarı alt ölçeklerine ilişkin tükenmişlik düzeyleri üzerindeki etkisinin anlamsız olduğu görülmektedir. Rehber öğretmenlerin mesleki tükenmişlik düzeyleri, hizmet verdikleri eğitim kademesinin (okul öncesi-ilkokul) ve cinsiyetin ortak etkisine bağlı olarak Duygusal Tükenme, Duyarsızlaşma ve Kişisel Başarı alt ölçeklerinde anlamlı bir farklılık göstermemiştir. Rehber öğretmenlerin mesleki tükenmişlik düzeyleri, yaş ve hizmet verdikleri eğitim kademesinin (okul öncesi-ilkokul) ortak etkisine bağlı olarak Duygusal Tükenme, Duyarsızlaşma ve Kişisel Başarı alt ölçeklerinde anlamlı bir farklılık göstermemiştir. Ayrıca, rehber öğretmenlerin mesleki tükenmişlik düzeyleri, medeni durumları ve hizmet verdikleri eğitim kademesinin (okul öncesi-ilkokul) ortak etkisine bağl1 olarak Duygusal Tükenme, Duyarsızlaşma ve Kişisel Başarı alt ölçeklerinde anlamlı bir farkl1l1k göstermemiştir. 
Çalışmanın sonunda, okul öncesi eğitim kurumlarında ve ilkokullarda görev yapacak rehber öğretmenlerin mesleki tükenmişlik düzeylerinin düşürülmesi için, görev tanımlarının ve özellikle kendilerinden beklenen hizmetlerin netleştirilmesinin ve iş tanımları içerisinde yer almayan görevlendirmelere maruz bırakılmamalarının etkili olacağı düşünülmektedir.

Bundan sonra yapılacak çalışmalarda, okul öncesi eğitim kurumlarında görev yapan rehber öğretmenlerin mesleki tükenmişlikleri karma araştırma yöntemi kullanılarak hem nicel hem de nitel veri toplama yöntemleriyle daha derinlemesine incelenebilir. Bununla birlikte, okul öncesi eğitim kurumlarında çalışan rehber öğretmenlerin mesleki tükenmişlikleri ile ortaokul, lise ve Rehberlik Araştırma Merkezlerinde görev yapan rehber öğretmenlerin mesleki tükenmişlikleri karşılaştırılabilir. Bu çalışmada, Doğu ve Güneydoğu Anadolu Bölgelerinde görev yapan rehber öğretmenlerin mesleki tükenmişlikleri incelenmiştir. Diğer bölgelerde görev yapan rehber öğretmenlerin mesleki tükenmişliklerine ilişkin çalışmalar yapılabilir. Ayrıca, bu çalışmada sadece resmi okullarda görev yapan rehber öğretmenler çalışma kapsamına alınmıştır. Başka çalışmalarda özel okullarda görev yapan rehber öğretmenlerin mesleki tükenmişlikleri incelenebilir.

\section{Makalenin Bilimdeki Konumu (Yeri)}

Eğitim Bilimleri Bölümü/ Psikolojik Danışma ve Rehberlik Anabilim Dalı

\section{Makalenin Bilimdeki Özgünlüğü}

Erken yaşlarda verilen eğitimin önemi düşünüldüğünde bu kademelerde sunulan rehberlik hizmetlerinin önemi büyüktür. Bu hizmetlerin amacına ulaşmasında ise, rehber öğretmenlerin hayati bir rolü olduğu ortadadır. Bununla birlikte sunulan hizmetin kalitesini belirleyen önemli unsurlardan biri olarak kabul edilen tükenmişlik, iş gücü, zaman ve emek kaybına, işten ayrılmalara ve hizmetin kalitesinin düşmesine sebep olabilmektedir. Buna 
paralel olarak, okul öncesi eğitim kurumlarında rehber öğretmenlerin görev alıp almayacaklarına ilişkin hızlı değişiklikler olurken, hali hazırda bu kademede görev yapan rehber öğretmenlerin mesleki tükenmişliklerinin ilkokul kademesindeki rehber öğretmenlerin tükenmişlikleriyle karşılaştırılmasının, özellikle okul öncesinde sunulan rehberlik hizmetleri hakkında da bir ipucu verebileceği düşünülmektedir.

\section{Kaynaklar}

Acun, M. (2010). Bazl değişkenlere göre biyoloji öğretmenlerinin mesleki tükenmişlik düzeylerinin incelenmesi. (Yayımlanmamış yüksek lisans tezi), Dicle Üniversitesi, Diyarbakir.

Akman, B., Taşkın, N., Özden, Z., ve Çörtü, F. (2010). Okul öncesi öğretmenlerinde tükenmişlik üzerine bir çalışma. İlköğretim Online, 9(2), 807-815.

Akten, S. (2007). Rehber öğretmenlerin mesleki tükenmişlik düzeylerinin incelenmesi. (Yayımlanmamış yüksek lisans tezi), Trakya Üniversitesi, Edirne.

Amasralı, A. (2016). Ortaokul ve lise matematik öğretmenlerinin örgütsel sinizm tutumları ile mesleki tükenmişlik düzeyleri arasındaki ilişki (Amasya ili örneği). (Yayımlanmamış yüksek lisans tezi), Ondokuz Mayıs Üniversitesi, Samsun.

Arı, E. (2015). Öğretmenlerin iş doyumlarının mesleki tükenmişlik üzerine etkisinin yapısal eşitlik modeli ile araştırılması. Uluslararası Sosyal Araştırmalar Dergisi, 8(39), 549565.

Aslan, N. (2009). Kars ili ilköğretim okullarında görev yapan ögretmenlerde mesleki tükenmişlik düzeyi. (Yayımlanmamış yüksek lisans tezi), Kafkas Üniversitesi, Kars. 
Aydemir, S. (2014). Milli Eğitim Bakanlı̆̆ına bă̆lı çalışan rehber öğretmenlerin yöneticilerinin liderlik tarzını algılamaları ile tükenmişlik düzeyleri arasındaki ilişkinin incelenmesi. (Yayımlanmamış yüksek lisans tezi), Maltepe Üniversitesi, İstanbul.

Bardhoshi, G., Schweinle, A., ve Duncan, K. (2014). Understanding the impact of school factors on school counselor burnout: A mixed-methods study. The Professional Counselor, 4(5), 426-443.

Başol, G., ve Altay, M. (2009). Eğitim yöneticisi ve öğretmenlerin mesleki tükenmişlik düzeylerinin incelenmesi. Kuram ve Uygulamada Eğitim Yönetimi, 15(58), 191-216.

Başören, M. (2005). Çeşitli değişkenlere göre rehber ögretmenlerinin tükenmişlik düzeylerinin incelenmesi (Zonguldak ili örneği). (Yayımlanmamış yüksek lisans tezi), Zonguldak Karaelmas Üniversitesi, Zonguldak.

Baydar, H. Ö. (2013). İlkokul ve ortaokulda görev yapan beden eğitimi öğretmenlerinin yaşam doyumları ve mesleki tükenmişlik düzeylerinin incelenmesi. (Yayımlanmamış yüksek lisans tezi), Gazi Üniversitesi, Ankara.

Bayrakdar, N. (2014). Din kültürü ve ahlak bilgisi ögretmenlerinin mesleki tükenmişlik algıları. (Yayımlanmamış doktora tezi), Erciyes Üniversitesi, Kayseri.

Belgi, S. (2016). Lisede çalışan rehber öğretmenlerin mesleki öz yeterlik algıları ve mesleki tükenmişliklerinin incelenmesi (İstanbul ili Bahçelievler ilçesi örneği). (Yayınlanmamış yüksek lisans tezi), Nişantaşı Üniversitesi, İstanbul.

Cohen, J. (1988). Statistical power analysis for the behavioral sciences (2nd ed.). Hillsdale, New Jersey: Lawrence Erlbaum Associates.

Creswell, J. W. (2013). Research design: Qualitative, quantitative, and mixed methods approaches (4th ed.). Thousand Oaks: Sage Publications. 
Çatır, V. (2014). İkili öğretim yapan ilköğretim kurumlarında (ilkokul-ortaokul) görevli yöneticilerin mesleki tükenmişlik düzeyleri ile örgütsel bağlılıkları arasındaki ilişki. (Yayımlanmamış yüksek lisans tezi), Yeditepe Üniversitesi, İstanbul.

Çolakoğlu, İ. (2014). Ortaokullarda görev yapan müzik öğretmenlerinin mesleki tükenmişlik düzeylerinin incelenmesi. (Yayımlanmamış yüksek lisans tezi), İstanbul Aydın Üniversitesi-Yıldız Teknik Üniversitesi, Sosyal Bilimler Enstitülerinin Ortak Yürüttükleri Yüksek Lisans Programı, İstanbul.

Dalçiçek, E. (2016). Okul öncesi eğitim kurumlarında ve ilkokul kademesinde görev yapan rehber öğretmenlerin mesleki doyumlarının karşılaştırılması. (Yayımlanmamış yüksek lisans tezi), Yüzüncü Y1l Üniversitesi, Van.

Diri, M. S., ve Kıral, E. (2016). Ortaokul öğretmenlerinin iş doyumlarının mesleki tükenmişlik düzeylerine etkisi. Mehmet Akif Ersoy Üniversitesi Ĕgitim Fakültesi Dergisi, 39, 125-149.

Erdemoğlu Şahin, D. (2007). Öğretmenlerin mesleki tükenmişlik düzeyleri (Ankara ili ilköğretim ve ortaöğretim okulları örneği). (Yayımlanmamış yükssek lisans tezi), Gazi Üniversitesi, Ankara.

Eren, R. (2014). Milli Ĕ̆itim Bakanlı̆̆ına bağlı resmi ve bağımsız anaokullarındaki rehberlik ve psikolojik danışma faaliyetlerinin incelenmesi. (Yayımlanmamış yüksek lisans tezi), Necmettin Erbakan Üniversitesi, Konya.

Ergin, C. (1992). Akademisyenlerde tükenmişlik ve çeşitli stres kaynaklarının incelenmesi. Hacettepe Üniversitesi Edebiyat Fakültesi Dergisi, 12(1-2), 37-50.

Erkul, A. (2014). Meslek lisesi öğretmenlerinin mesleki tükenmişlik düzeyi. (Yayımlanmamış yüksek lisans tezi), Bahçeşehir Üniversitesi, İstanbul. 
Ertürk, M. (2012). Özel ve devlet okullarında çalışan okul öncesi ögretmenlerin demografik değişkenlere bağlı olarak mesleki tükenmişlik ve anksiyete düzeylerinin karşılaş̧tırılması. (Yayımlanmamış yüksek lisans tezi), Maltepe Üniversitesi, İstanbul.

Gündoğdu, G. B. (2013). Sınıf ögrretmenlerinin iş doyumu ve mesleki tükenmişlik düzeyleri üzerine bir çalışma: Mersin ili örneği. (Yayımlanmamış yüksek lisans tezi), Çağ Üniversitesi, Mersin.

Gürbüz, Z. (2008). Kars ilinde görevli okul öncesi ögretmenlerinin iş tatmin düzeyleri ve mesleki tükenmişlik düzeylerinin incelenmesi. (Yayımlanmamış yüksek lisans tezi), Marmara Üniversitesi, İstanbul.

Fraenkel, J. R., \& Wallen, N. E. (2006). How to design and evaluate research in education (6thed.). McGraw-Hill, Inc.

Freudenberger, H. J. (1974). Staff burn-out. Journal of Social Issues, 30(1), 159-165.

Kaçmaz, N. (2005). Tükenmişlik (Burnout) sendromu. İstanbul Tıp Fakültesi Dergisi, 68, 2932.

Kardeş, S. (2014). Okul öncesi ĕgitim kurumu yönetici ve ögrretmenlerinin rehber ögretmenlerin rollerine ilişkin algıları. (Yayımlanmamış yüksek lisans tezi). Hacettepe Üniversitesi, Ankara.

Khezerlou, E. (2012). A cross-cultural examination of English language teachers' job burnout: The case of Iran and Turkey. (Yayımlanmamış doktora tezi), Hacettepe Üniversitesi, Ankara.

Koralay, F.D. (2014). Illkokullarda görev yapan öğretmenlerin mesleki tükenmişlik düzeyi. (Yayımlanmamış yüksek lisans tezi), Dokuz Eylül Üniversitesi, İzmir. 
Lee, R. T., \& Ashforth, B. E. (1996). A meta-analytic examination of the correlates of the three dimensions of job burnout. Journal of Applied Psychology, 81, 123-133. doi:10.1037/0021-9010.81.2.123

Maslach, C. (1981). The burnout syndrome. Current research, theory and interventions, 3, 49-56.

Maslach, C. (1982). Burnout: The cost of caring. New Jersey: Prentice- Hall, Inc., Englewood Cliffs.

Maslach, C. (2006). Stress and burnout. In A. M. Rossi, P. L. Perreve and S. L. Sauter (Eds.) Stress and quality of working life. International Stress Management Association.

Maslach, C., \& Leiter, M. P. (1997). The truth about burnout: How organizations cause personal stress and what do about it. NA: Jossey-Bass.

Maslach, C., Schaufeli, W. B., \& Leiter, M. P. (2001). Job burnout. Annual Review Psychology, 5, 397-422.

MEB. (2001). Rehberlik ve psikolojik danışma hizmetleri yönetmeliği. Ankara: Milli Eğitim Bakanlığı Özel Eğitim ve Rehberlik Hizmetleri Genel Müdürlüğü.

Özyürek, A., Gümüş, H., ve Doğan, S. (2012). Öğretmen ve okul yöneticilerinin tükenmişlik ve yaşam doyumunun incelenmesi. International Journal of Human Sciences, 9(2), 893903.

Resmi Gazete. (2016). 25.11.2016 Sayılı Resmi Gazete.

http://www.resmigazete.gov.tr/main.aspx?home=http://www.resmigazete.gov.tr/eskiler/ 2016/11/20161125.htm\&main=http://www.resmigazete.gov.tr/eskiler/2016/11/2016112 5.htm 
Seçer, İ. (2011). Psikolojik danışmanların tükenmişlik düzeylerinin çeşitli değişkenler açısından incelenmesi. (Yayımlanmamış yüksek lisans tezi), Atatürk Üniversitesi, Erzurum.

Seferoğlu, S. S., Yıldız, H., ve Avcı Yücel, Ü. (2012). Öğretmenlerde tükenmişlik: Tükenmişliğin göstergeleri ve bu göstergelerin çeşitli değişkenler açısından incelenmesi. Ĕ̈itim ve Bilim, 39(174), 348-364.

Seğmenli, S. (2001). Rehber öğretmenlerin tükenmişlik düzeylerinin incelenmesi. (Yayımlanmamış yüksek lisans tezi), Hacettepe Üniversitesi, Ankara.

Şahin, F., ve Şahin, D. (2013). Bilim ve sanat merkezlerinde çalışan öğretmenlerin tükenmişlik düzeyinin incelenmesi. Journal of Gifted Education Research, 1(2), 51-66.

Tezel Şahin, F., ve Sak, R. (2016). A comparative study of male and female early childhood teachers' job satisfaction in Turkey. Early Childhood Education Journal, 44, 473-481.

Tunaboylu, M. (2015). Illkokul ve ortaokul öğretmenlerinin mesleki tükenmişlik düzeyleri (İzmir ili torbalı ilçesi örneği). (Yayımlanmamış yüksek lisans tezi), Okan Üniversitesi, İstanbul.

Turtulla, S. (2014). Examining levels of job burnout among teachers working in Kosova in terms of different variables: Proposing a psychological and counselling group program for managing burnout based on narrative therapy. (Yayımlanmamış doktora tezi), Sakarya Üniversitesi, Sakarya.

Uğuz, S. (2016). Adana'da mesleki ve teknik Anadolu liselerinde Ingilizce öğretmenlerinin mesleki tükenmişlik düzeylerinin incelenmesi üzerine bir çalışma. (Yayımlanmamış yüksek lisans tezi), Çukurova Üniversitesi, Adana. 
Umay, G. (2015). Psikolojik danışman ve rehberlik ögretmenlerinin iş doyumu ve tükenmişlik düzeylerinin ilişkisi. (Yayımlanmamış yüksek lisans tezi), Yeditepe Üniversitesi, İstanbul.

Vural, B. (2004). Her öğretmen rehberdir. İstanbul: Hayat Yayıncıl1k.

Yalçın, S. (2013). İlköğretim okulu ögrretmenlerinin mesleki tükenmişlik düzeyleri ile stres, psikolojik dayanıklılık ve akademik iyimserlik arasındaki ilişki. (Yayınlanmamış yüksek lisans tezi), Gazi Üniversitesi, Ankara.

Yerlikaya, İ., Sak, R., ve Şahin Sak, İ. T. (2014). Okul öncesi eğitimde psikolojik danışma ve rehberlik hizmetleri: okul öncesi öğretmen adaylarının ve psikolojik danışman adaylarının görüşleri. Uşak Üniversitesi Sosyal Bilimler Dergisi, 7(2), 286-299.

Yeşilyaprak, B. (2006). Eğitimde rehberlik hizmetleri gelişimsel yaklaşım. (13. Baskı). Ankara: Nobel Yayın Dağıtım.

Yıldırım, S. S. (2009). Ortaöğretim kurumları yöneticilerinin mesleki tükenmişlik düzeylerinin çeşitli değişkenler açısından incelenmesi (İstanbul ili Anadolu yakası örneği). (Yayınlanmamış yüksek lisans tezi), Maltepe Üniversitesi, İstanbul.

Yıldız, E. (2011). Eğitimcilerde tükenmişlik (rehber öğretmenler üzerinde bir araştırma). (Yayınlanmamış yüksek lisans tezi), Sakarya Üniversitesi, Sakarya.

Yoğun-Erçen, A. E. (2007). Öğretmenlerin mesleki tükenmişlik düzeyleri: Mersin ilinde karş1laştırmalı bir inceleme. Çukurova Üniversitesi Ĕ̆itim Fakültesi Dergisi, 3(34), 1-8. 